POLITICAL ORDER IN CHANGING SOCIETIES

\author{
Written under the auspices of the \\ Center for International Affairs \\ Harvard University
}

\author{
Delivered in part as the \\ Henry L. Stimson Lectures \\ Yale University
}


This page intentionally left blank 


\title{
Political Order in Changing Societies
}

\author{
Samuel P. Huntington
}

Foreword by Francis Fukuyama

New Haven and London, Yale University Press 
Copyright $@ 1968$ by Yale University.

Copyright (c) renewed 1996 by Samuel P. Huntington.

Foreword (C) 2006 by Yale University.

All rights reserved.

This book may not be reproduced, in whole or in part, including illustrations, in any form (beyond that copying permitted by Sections 107 and 108 of the U.S. Copyright Law and except by reviewers for the public press), without written permission from the publishers.

Printed in the United States of America.

Library of Congress Control Number: 2005932004

ISBN-13: 978-o-300-1 1620-5 (cloth : alk. paper)

ISBN-10: 0-300-1 1620-9 (cloth : alk. paper)

A catalogue record for this book is available from the British Library.

The paper in this book meets the guidelines for permanence and durability of the Committee on Production Guidelines for Book Longevity of the Council on Library Resources.

$\log _{976543}$ 


\section{For Nancy, \\ Timothy, and Nicholas}


This page intentionally left blank 